BIOCHEMISTRY OF PARASITIC HELMINTHS 


\section{BIOCHEMISTRY OF PARASITIC HELMINTHS}

\section{JOHN BARRETT}

Department of Zoology

The University College of Wales

Aberystwyth, Dyfed 


\section{(C) John Barrett 1981}

Softcover reprint of the hardcover 1st edition 1981 978-0-333-25668-8

All rights reserved. No part of this publication may be reproduced or transmitted, in any form or by any means, without permission

First published 1981 by

The Scientific and Medical Division

MACMILLAN PUBLISHERS LTD

London and Basingstoke

Associated companies throughout the world

Typeset in Great Britain by

Reproduction Drawings Ltd

Sutton Surrey

\section{British Library Cataloguing in Publication Data}

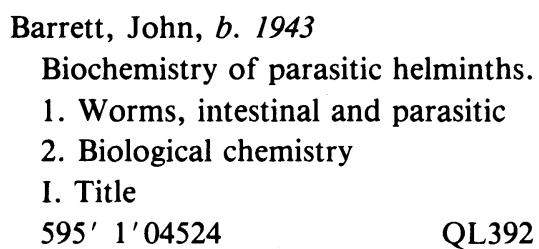

ISBN 978-0-333-25669-5 ISBN 978-1-349-86119-4 (eBook)

DOI 10.1007/978-1-349-86119-4

To Sara and Kate

This book is sold subject to the standard conditions of the Net Book Agreement

The paperback edition of this book is sold subject to the condition that it shall not, by way of trade or otherwise, be lent, resold, hired out, or otherwise circulated without the publisher's prior consent in any form of binding or cover other than that in which it is published and without a similar condition including this condition being imposed on the subsequent purchaser 


\section{Contents}

Preface

1. Introduction to Parasite Biochemistry 1

1.1. The Parasite's Environment 2

1.1.1. Oxygen tension 3

1.1.2. Carbon dioxide tension and other gases 4

1.1.3. Oxidation-reduction potential 4

1.1.4. Hydrogen ion concentration 5

1.1.5. Osmotic pressure 6

1.1.6. Temperature 6

1.1.7. Bile salts $\quad 7$

1.1.8. Other factors $\quad 7$

1.2. Parasites as Invertebrates 8

1.3. Technical Problems in Parasite Biochemistry 9

$\begin{array}{ll}\text { 1.4. Summary and Conclusions } & 10\end{array}$

1.5. General Reading 10

2. Biochemical Constituents 12

2:1. Inorganic Compounds 12

2.2. Carbohydrates 15

2.2.1. Reserve carbohydrates $\quad 15$

$\begin{array}{ll}\text { 2.2.2. Structural carbohydrates } & 17\end{array}$

$\begin{array}{ll}2.2 .3 \text {. Mucopolysaccharides } & 18\end{array}$

2.2.4. Immunologically active polysaccharides 19

2.3. Lipids 19

2.3.1. Fatty acids $\quad 20$

2.3.2. Acylglycerols $\quad 24$

2.3.3. Phosphoglycerides 27

2.3.4. Sphingolipids $\quad 29$

2.3.5. Ascarosides 31

2.3.6. Waxes $\quad 34$

2.3.7. Terpenes $\quad 35$

$\begin{array}{lll}2.3 .8 . & \text { Steroids } & 39\end{array}$

2.3.9. Distribution of lipids $\quad 40$ 
2.4. Amino Acids and their Derivatives

2.4.1. Free amino acid pools $\quad 42$

2.4.2. Amino acid derivatives 43

2.5. Proteins 43

2.5.1. Structural proteins $\quad 44$

2.5.2. Haemoglobin 49

2.5.3. Contractile proteins $\quad 55$

2.5.4. Ascaridine 56

2.5.5. Soluble proteins $\quad 56$

2.6. Nucleic Acids and their Components $\quad 56$

$\begin{array}{ll}\text { 2.6.1. Deoxyribonucleic acid } & 57\end{array}$

2.6.2. Ribonucleic acid 63

2.6.3. Nucleotides and nucleosides 64

2.7. Vitamins and Cofactors $\quad 65$

2.7.1. Vitamins 65

2.7.2. Cofactors 66

2.8. Hormones and Hormone Analogues 66

2.8.1. Invertebrate hormones 66

2.8.2. Vertebrate hormones 67

2.9. Summary and Conclusions $\quad 68$

2.10. General Reading $\quad 69$

$\begin{array}{ll}\text { 2.11. References } & 69\end{array}$

3. Catabolism and Energy Production 72

3.1. Carbohydrate Catabolism 72

3.1.1. Carbohydrate reserves 73

3.1.2. Pathways of carbohydrate catabolism 73

3.1.3. Carbohydrate catabolism in A. lumbricoides 75

3.1.4. Helminths that rely predominantly on carbon dioxide

3.1.5. The reduction of fumarate to succinate 90

3.1.6. Helminths that rely predominantly on glycolysis 91

3.1.7. The pyruvate kinase/phosphoenolpyruvate carboxykinase ratio $\quad 92$

3.1.8. The role of the tricarboxylic acid cycle 94

3.1.9. The significance of mixed fermentations 98

3.1.10. Catabolism of hexoses other than glucose 103

3.1.11. Rate of carbohydrate catabolism in parasitic helminths 105

3.1.12. The pentose phosphate pathway 105

3.1.13. Carbohydrate catabolism in the free-living and $\begin{array}{ll}\text { intermediate stages of helminths } & 107 \\ \text { 3.2. Terminal Oxidation } & 109 \\ \text { 3.2.1. Cytochrome chains } & 110\end{array}$

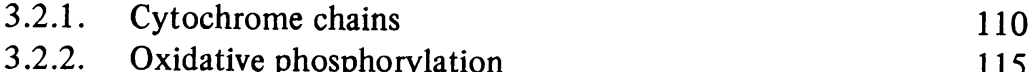

3.2.2. Oxidative phosphorylation 115

3.2.3. Reduction of fumarate 115

3.2.4. NADH shuttle system 116 
3.2.5. Metabolite transport systems 118

3.2.6. Microsomal and other cytochrome systems 119

3.2.7. Utilisation of oxygen by oxidases and oxygenases 119

3.2.8. Superoxide dismutase, catalase and peroxidase 121

3.2.9. The role of oxidative processes in parasitic helminths 122

3.2.10. Carbon dioxide transport 124

3.3. Lipid Catabolism 125

3.3.1. Fatty acid catabolism 125

3.3.2. Role of the $\beta$-oxidation sequence in helminths $\quad 127$

3.3.3. Excretion and accumulation of lipids 128

3.3.4. Free-living and intermediate stages 129

3.4. Amino Acid Catabolism 129

3.4.1. Removal of the amino group 130

3.4.2. Metabolism of carbon skeletons 133

3.4.3. Decarboxylation of amino acids 136

3.4.4. Cofermentation of amino acids and carbohydrate $\quad 137$

3.5. Pyrimidine and Purine Catabolism 138

3.5.1. Pyrimidine catabolism 138

3.5.2. Purine catabolism 139

3.6. Nitrogenous Excretion 140

3.6.1. Ammonia production 140

3.6.2. Urea production 141

3.6.3. Uric acid production $\quad 142$

3.6.4. Amine production 143

3.6.5. Excretion of amino acids and peptides 143

3.6.6. Rates of nitrogenous excretion in parasitic helminths $\quad 144$

3.7. Summary and Conclusions 144

3.8. General Reading 146

3.9. References 146

4. Nutrition and Biosynthesis 149

4.1. Digestion and Absorption of Nutrients 149

4.1.1. Digestive enzymes 149

4.1.2. Hatching, exsheathing and tissue-penetrating enzymes 156

4.1.3. Anticoagulants and antienzymes 158

4.1.4. Nature of the absorptive surface 159

4.1.5. Absorption mechanisms 161

4.1.6. Uptake in helminths 166

4.1.7. Carbohydrate uptake 168

4.1.8. Amino acid uptake 173

4.1.9. Lipid uptake 179

4.1.10. Purine, pyrimidine and nucleoside transport 180

4.1.11. Vitamins and related compounds 184

4.1.12. Ion and water transport 185

4.1.13. Significance of uptake mechanisms 186 
4.2. Biosynthesis of Carbohydrates 188

4.2.1. Synthesis from non-hexose precursors 188

4.2.2. Synthesis of monosaccharides and disaccharides 192

4.2.3. Synthesis of polysaccharides 193

4.3. Biosynthesis of Lipids 195

4.3.1. Fatty acid synthesis $\quad 195$

4.3.2. Triacylglycerol synthesis 198

4.3.3. Steroid synthesis 200

4.3.4. Ascaroside synthesis 204

4.3.5. Phospholipid and sphingolipid synthesis 205

4.4. Biosynthesis of Amino Acids and their Derivatives 208

$\begin{array}{ll}\text { 4.4.1. Synthesis of amino acids } & 208\end{array}$

4.4.2. Amino acid derivatives 211

4.5. Biosynthesis of Proteins 218

$\begin{array}{ll}\text { 4.5.1. General protein synthesis } & 219\end{array}$

4.6. Biosynthesis of Nucleotides and Nucleic Acids 219

4.6.1. Purine nucleotide synthesis 220

4.6.2. Pyrimidine nucleotide synthesis 222

4.6.3. Deoxyribonucleotide synthesis 225

$\begin{array}{ll}\text { 4.6.4. Nucleic acid synthesis } & 225\end{array}$

4.7. Biosynthesis of Vitamins and Cofactors 228

4.8. Detoxication Reactions 231

4.9. Nutrition of Parasitic Helminths $\quad 233$

$\begin{array}{ll}\text { 4.10. Summary and Conclusions } & 237\end{array}$

4.11. General Reading 239

4.12. References $\quad 239$

5. Metabolic Regulation 245

5.1. Cellular Regulation 245

\begin{tabular}{ll} 
5.1.1. & General theory \\
\hline & 245
\end{tabular}

5.1.2. Control of carbohydrate catabolism in helminths 250

$\begin{array}{ll}\text { 5.1.3. Glycolysis } & 250\end{array}$

$\begin{array}{ll}\text { 5.1.4. Pyruvate kinase/phosphoenolpyruvate carboxykinase } & \\ \text { branch point } & 257\end{array}$

5.1.5. Malate branch point 262

5.1.6. The tricarboxylic acid cycle 262

5.1.7. Hormones and 3',5'-cyclic-AMP 264

$\begin{array}{ll}\text { 5.1.8. Energy charge } & 265\end{array}$

5.1.9. Phosphorylation potential 267

$\begin{array}{ll}\text { 5.1.10. Phosphagens } & 267\end{array}$

5.2. Developmental Regulation 268

5.2.1. Metabolic changes during the life-cycle 268

5.2.2. The role of oxygen and carbon dioxide 270

$\begin{array}{ll}\text { 5.2.3. The role of temperature } & 270\end{array}$

$\begin{array}{ll}\text { 5.2.4. Other environmental factors } & 272\end{array}$

5.2.5. Timing of the metabolic changes 272 
5.2.6. Dormancy and delayed development 274

5.2.7. Environmental and genetic control 275

$\begin{array}{ll}\text { 5.3. Summary and Conclusions } & 277\end{array}$

$\begin{array}{ll}\text { 5.4. General Reading } & 278\end{array}$

$\begin{array}{ll}\text { 5.5. References } & 278\end{array}$

6. General Summary 281

7. Appendixes 283

7.1. Possible Mode of Action of Some Anthelmintics 283

7.2. List of Abbreviated Names 286

7.3. List of Other Abbreviations 289

$\begin{array}{lr}\text { Systematic Index } & 291\end{array}$

$\begin{array}{ll}\text { Subject Index } & 295\end{array}$ 


\section{Preface}

It is the aim of this book to give a comparative account of the biochemistry of parasitic helminths and to relate the biochemistry of parasites not only to that of mammals but also to that of free-living invertebrates. The emphasis is on regulation and deals with metabolic control both at the cellular and at the developmental level.

A difficulty in parasite biochemistry is that the information is patchy, some aspects are known in great detail and others not at all. In the text, I have tried to indicate those areas of parasite biochemistry that have been neglected, in the past, since, in some ways, what is not known about helminths is almost as interesting as what is known.

The book does not deal with nerve-muscle physiology, nor with osmoregulation, and nor does it discuss, in detail, the mode of action of anthelmintics.

However, a table of the possible biochemical modes of action of the more important anthelmintics is given in Appendix 7.1.

For the purpose of this book, I have taken helminths to include acanthocephalans, cestodes, trematodes, nematodes and nematomorphs. Throughout the text, Ascaris lumbricoides is used, rather than A. suum or var. suis. In almost all cases, it is the ascarid from pigs which has been investigated and not the human worm.

The literature has been covered up to December 1978, and the sheer number of references poses a severe problem. The compromise I have adopted is to have a general reading list composed of relevant reviews at the end of each chapter, as well as the specific references. Any reference that can easily be found from the general reading list is not included in the specific list; in particular, T. von Brand's book, The Biochemistry of Parasites (2nd edn, 1973), gives comprehensive references to all of the literature prior to 1973. In this way, it should be possible to find the reference to any particular point of interest, yet keep the reference lists to manageable proportions.

It is inevitable that some of the information in this book will rapidly become out of date or prove to be incorrect. What I hope the text will provide is a framework within which the reader can place new developments in context.

In conclusion, I should like to thank those colleagues who have sent me reprints or allowed me to quote from their unpublished work. Also, I am grateful to R.W. Walker, J. M. Paul and, in particular, G. M. Lloyd for reading and commenting on various aspects of the manuscript. 